\title{
PENINGKATAN KOMPETENSI GURU KIMIA MELALUI PELATIHAN MODEL-MODEL PEMBELAJARAN INOVATIF DI BANYUWANGI
}

\author{
Oleh: \\ Utiya Azizah ${ }^{1}$, Suyono ${ }^{2}$, Bertha Yonata ${ }^{3}$ \\ 1,2,3 Jurusan Kimia FMIPA Unesa \\ utiyaazizah@unesa.ac.id
}

\begin{abstract}
Abstrak
Telah dilakukan kegiatan pengabdian kepada masyarakat (PKM) di Kabupaten Banyuwangi. Tujuan kegiatan adalah mendeskripsikan pemahaman guru Kimia terhadap materi model-model pembelajaran inovatif, kemampuan guru Kimia dalam menyusun kegiatan-kegiatan pembelajaran berbasis model-model pembelajaran inovatif, dan respon guru selama mengikuti kegiatan pelatihan model-model pembelajaran inovatif. Langkah-langkah kegiatan pengabdian kepada masyarakat yang dilakukan adalah kegiatan penyegaran materi model-model pembelajaran inovatif dan penyusunan Rencana Pelaksanaan Pembelajaran (RPP) yang menerapkan model-model pembelajaran inovatif. Evaluasi dilakukan dengan tes pemahaman terhadap materi model-model pembelajaran inovatif dengan khalayak sasaran dan angket kepada peserta untuk mendapatkan data respon terhadap pelaksanaan pelatihan. Berdasarkan data hasil pelatihan, dapat disimpulkan bahwa: (1) pemahaman materi model-model pembelajaran inovatif guru MGMP kimia di Kabupaten Banyuwangi setelah kegiatan pembelajaran dalam rangka penyegaran materi model-model pembelajaran inovatif termasuk kategori baik dan sangat baik, (2) kemampuan guru MGMP kimia di Kabupaten Banyuwangi dalam menyusun kegiatan-kegiatan pembelajaran berbasis model-model pembelajaran inovatif adalah baik dan sangat baik, dan (3) secara umum respon guru MGMP kimia di Kabupaten Banyuwangi terhadap kegiatan pelatihan ini adalah baik dan sangat baik.
\end{abstract}

Kata Kunci: pelatihan, model pembelajaran inovatif, peningkatan kompetensi

\begin{abstract}
A community service (PKM) has been in Banyuwangi. Its objective is to describe the understanding of chemistry teacher against the material of innovative learning models, ability of chemistry teacher in preparing learning activities based innovative learning models, and the response of the teachers during the training activities of innovative learning models. Steps the activities of community service are activities undertaken refresher innovative learning models material and making of lesson plan (RPP) that implement innovative learning models. Evaluation is done by testing the understanding of the material innovative learning models with target audiences and questionnaires to participants to get the data in response to the implementation of the training. Based on data from the results of the training, it can be concluded that: (1) retention of material models of innovative learning chemistry teacher MGMP in Banyuwangi after learning activities in order to refresh the material of innovative learning models categorized as good and very good, (2) the ability of chemistry teachers MGMP in Banyuwangi in formulating activities based learning models of innovative learning is good, and (3) the general response chemistry teacher MGMPs in Banyuwangi on the activities of the training is good and very good.
\end{abstract}

Keywords: training, innovative learning models, increased competence

\section{PENDAHULUAN}

Guru sebagai tenaga professional memiliki tugas utama mendidik, mengajar, membimbing, mengarahkan, melatih, menilai, dan mengevaluasi peserta didik, mulai dari pendidikan anak usia dini jalur pendidikan formal, pendidikan dasar sampai dengan pendidikan menengah (Undang-undang Nomor 20 tahun 2003). Untuk menunjang profesinya, sebagaimana yang diamanatkan dalam Permeneg PAN dan RB Nomor 16 tahun 2009 tentang jabatan fungsional guru dan angka kreditnya, seorang guru juga dituntut memiliki kewajiban, dan bertanggungjawab untuk meningkatkan dan mengembangkan kualifikasi akademik dan kompetensi secara berkelanjutan sejalan dengan perkembangan ilmu pengetahuan, teknologi, dan seni.

Menurut Daniel (2007) terdapat 5 (lima) kompetensi professional, yaitu: 1) menguasai 
materi, struktur, konsep dan pola pikir keilmuan yang mendukung mata pelajaran yang diampu, 2) menguasai kompetensi dasar mata pelajaran yang diampu, 3) mengembangkan materi pelajaran yang diampu secara kreatif dalam proses pembelajaran, 4) mengembangkan keprofesian secara berkelanjutan dengan melakukan tindakan reflektif, dan 5) memanfaatkan teknologi informasi dan komunikasi untuk berkomunikasi dan mengembangkan diri. Dengan mencermati pendapat di atas, pengembangan materi pelajaran yang diampu secara kreatif dalam proses pembelajaran merupakan salah satu kompetensi profesional guru. Hal tersebut diperkuat dengan amanah kurikulum 2013 (Permendikbud nomor 103, 2014) bahwa pembelajaran yang dilaksanakan, harus berbasis aktivitas dengan karakteristik: 1) interaktif dan inspiratif, 2) menyenangkan, menantang, dan memotivasi peserta didik untuk berpartisipasi aktif, 3) kontekstual dan kolaboratif , 4) memberikan ruang yang cukup bagi prakarsa, kreativitas, dan kemandirian peserta didik, dan 5) sesuai dengan bakat, minat, kemampuan, dan perkembangan fisik serta psikologis peserta didik.

Proses pembelajaran di kelas pada prinsipnya menggunakan pendekatan, strategi, model, dan metode yang mengacu pada karakteristik yang telah diuraikan di atas. Sesuai dengan Permendikbud tentang Standar Proses Pendidikan Dasar dan Menengah, kegiatan pembelajaran sepenuhnya diarahkan pada pengembangan ranah pengetahuan, keterampilan, dan sikap secara utuh melalui pendekatan saintifik dan diperkuat dengan penerapan model pembelajaran inovatif berbasis penyingkapan/penelitian (discoverylinquiry learning), pembelajaran berbasis proyek (project based learning), dan pembelajaran berbasis pemecahan masalah (problem based learning) (Permendikbud nomor 59, 2014).

Penyusunan perencanaan, pelaksanaan, dan evaluasi model pembelajaran merupakan rangkaian kegiatan yang utuh dan merupakan satu kesatuan yang tidak bisa dipisahkan satu dengan yang lainnya dalam suatu proses pembelajaran. Guru sebagai tenaga pendidik yang dituntut mampu melakukan itu semua untuk peningkatan kompetensi profesionalnya. Fakta yang terjadi pada guru-guru kimia yang tergabung dalam MGMP Kimia Kabupaten Banyuwangi menunjukkan bahwa masih banyak guru yang belum melakukan peningkatan kompetensinya, khususnya dalam meningkatkan kompetensi profesional dalam bidang mengembangkan materi pelajaran yang diampu secara kreatif melalui penerapan model pembelajaran inovatif. Para guru juga mengalami kesulitan memilih kegiatan yang dapat menunjang proses pembelajaran berbasis model pembelajaran inovatif tersebut karena sibuk dengan aktivitas rutin dalam mengajar serta kegiatan administratif lain.

\section{METODE PELAKSANAAN}

Khalayak sasaran dalam kegiatan PKM ini adalah para guru kimia MGMP di kabupaten Banyuwangi.

Dari berbagai metode kegiatan yang dapat dipilih dalam kegiatan PKM, dengan memperhatikan berbagai pertimbangan, maka tim PKM memilih metode kegiatan sebagai berikut.

1. Pembelajaran antara tim PKM dan guruguru dalam MGMP Kimia di Kabupaten Banyuwangi dalam rangka penyegaran materi model-model pembelajaran inovatif.

2. Pembelajaran antara tim PKM dan guruguru dalam MGMP Kimia di Kabupaten Banyuwangi dalam rangka penyegaran materi Memperbaiki Miskonsepsi dengan Strategi Conceptual Change.

3. Tim PKM membimbing guru-guru dalam MGMP Kimia di Kabupaten Banyuwangi melaksanakan kegiatan penyusunan Rencana Pelaksanaan Pembelajaran (RPP) yang menerapkan model-model pembelajaran inovatif, dalam rangka mendapatkan data:

a. Kemampuan guru MGMP Kimia di Kabupaten Banyuwangi dalam menyusun kegiatan-kegiatan pembelajaran berbasis model-model pembelajaran inovatif.

b. Pemahaman guru MGMP Kimia di Kabupaten Banyuwangi terhadap materi model-model pembelajaran inovatif.

4. Tim PKM memberikan angket kepada peserta untuk mendapatkan data respon peserta terhadap pelaksanaan pelatihan model-model pembelajaran inovatif.

\section{HASIL DAN PEMBAHASAN}

Hasil pemahaman guru MGMP Kimia di Kabupaten Banyuwangi setelah pembelajaran dalam rangka penyegaran tentang materi model-model pembelajaran inovatif dan strategi conceptual change untuk memperbaiki miskonsepsi diperoleh melalui data tes Pemahaman Model-model Pembelajaran Inovatif disajikan pada Tabel 1 dan di dukung oleh data deskripsi tentang aktivitas "Cek Konsepsi Diri tentang Asam dan Basa dengan Metode CRI." 
Tabel 1 Pemahaman Peserta terhadap Materi Model-Model Pembelajaran Inovatif

\begin{tabular}{clcc}
\hline No & \multicolumn{1}{c}{ Uraian } & Jawaban & Kategori \\
\hline 1 & $\begin{array}{l}\text { Pemahaman tentang model-model pembelajaran inovatif } \\
\text { dan strategi conceptual change untuk memperbaiki } \\
\text { miskonsepsi }\end{array}$ & Paham/Jelas & Baik \\
& $81,25 \%$ & \\
\hline 2 & $\begin{array}{l}\text { Pemahaman tentang pentingnya penerapan model-model } \\
\text { pembelajaran inovatif }\end{array}$ & $\begin{array}{c}\text { Paham/Jelas } \\
87,50 \%\end{array}$ & Sangat Baik \\
\hline 3. & $\begin{array}{l}\text { Pemahaman tentang karakteristik model-model } \\
\text { pembelajaran inovatif }\end{array}$ & $\begin{array}{c}\text { Paham/Jelas } \\
75,00 \%\end{array}$ & Baik \\
\hline 4. & $\begin{array}{l}\text { Pemahaman tentang pelaksanaan model-model } \\
\text { pembelajaran inovatif yang dapat memperkuat pendekatan } \\
\text { saintifik 5 M }\end{array}$ & Paham/Jelas & Baik \\
\hline 5. & $\begin{array}{l}\text { Pemahaman tentang pentingnya peranan strategi } \\
\text { conceptual change dalam penerapan model-model }\end{array}$ & Paham/Jelas & Sangat Baik \\
& pembelajaran inovatif & $87,50 \%$ & \\
\hline
\end{tabular}

Berdasarkan Tabel 1 terlihat bahwa materi model-model pembelajaran inovatif dan strategi conceptual change serta karakteristik model-model pembelajaran inovatif telah dipahami oleh peserta pelatihan dengan jelas. Demikian pula, pelaksanaan model-model pembelajaran inovatif yang dapat memperkuat pendekatan saintifik $5 \mathrm{M}$ juga telah dipahami oleh peserta pelatihan dengan jelas. Selain itu, peserta sangat memahami relevansi materi pelatihan dengan tugas mengajarnya yang mewujudkan pentingnya penerapan modelmodel pembelajaran inovatif dan peserta sangat yakin bahwa strategi conceptual change berperan penting dalam penerapan model-model pembelajaran inovatif.

Keyakinan para peserta pelatihan tentang peranan strategi conceptual change dalam penerapan model-model pembelajaran inovatif juga di dukung oleh hasil aktivitas peserta tentang "Cek Konsepsi Diri tentang Asam dan Basa dengan Metode CRI" yang memberikan hasil bahwa:

1. Dari 18 (delapan belas) pernyataan konseptual tentang asam dan basa, masih terdapat beberapa pernyataan konseptual yang dijawab salah dengan tingkat keyakinan tinggi (miskonsepsi) oleh para peserta pelatihan.

2. Terdapat 4 (empat) pernyataan konseptual tentang asam dan basa yang direspon secara miskonsepsi oleh sebagian besar peserta pelatihan, yaitu larutan-larutan dengan $\mathrm{pH}$ berbeda memiliki warna yang berbeda, $\mathrm{pH}$ adalah sebuah ukuran dari keasaman, di dalam semua reaksi netralisasi asam dan basa saling bereaksi hingga habis, dan jika jumlah atom hidrogen di dalam formula sebuah asam bertambah maka keasamannya menjadi lebih kuat.

Hasil kemampuan guru MGMP Kimia di Kabupaten Banyuwangi dalam menyusun kegiatan-kegiatan pembelajaran berbasis model pembelajaran inovatif diperoleh melalui data hasil penyusunan RPP secara berkelompok. Peserta pelatihan terbagi menjadi tiga kelompok yang disajikan pada Tabel 2.

Tabel 2 Kemampuan Menyusun Kegiatan-Kegiatan Pembelajaran Berbasis Model Pembelajaran Inovatif

\begin{tabular}{llccc}
\hline \multirow{2}{*}{ No } & & \multicolumn{3}{c}{$\begin{array}{c}\text { Nilai dan Kategori } \\
\text { Kelompok }\end{array}$} \\
\cline { 3 - 5 } & & $\mathbf{1}$ & $\mathbf{2}$ & $\mathbf{3}$ \\
\hline 1 & Perumusan indikator dan tujuan pembelajaran & 87,5 & 93,7 & 87,5 \\
\hline 2 & Pemilihan materi pembelajaran & 100 & 87,5 & 100 \\
\hline 3. & Pengorganisasian materi pembelajaran & 75,0 & 87,5 & 75,0 \\
\hline 4. & Pemilihan sumber belajar/medis pembelajaran & 87,5 & 93,8 & 87,5 \\
\hline 5. & Skenario pembelajaran & 93,8 & 93,8 & 93,8 \\
\hline 6. & Penilaian & 68,8 & 75,0 & 81,3 \\
\hline 7. & Penggunaan bahasa tulis & 75,0 & 75,0 & 75,0 \\
\hline
\end{tabular}


Utiya, A., dkk., Peningkatan Kompetensi Guru ...

Tabel 2 menunjukkan bahwa kemampuan peserta pelatihan dalam menyusun kegiatankegiatan pembelajaran berbasis model pembelajaran inovatif telah memperoleh kategori baik (nilai 69 - 84) pada kelompok 1 , serta sangat baik (nilai 85 - 100) pada kelompok 2 dan 3.

Topik pada kelompok 1 adalah struktur atom, guru merancang kegiatan-kegiatan pembelajarannya dengan menggunakan model pembelajaran berbasis proyek (project based learning). Semua komponen telah mendapatkan nilai baik, kecuali komponen penilaian mendapatkan nilai paling rendah (skor 2) pada aspek kelengkapan instrumen.

Kelompok 2 mendapatkan penilaian tertinggi diantara dua kelompok yang lain. Topik kelompok 2 adalah sifat koligatif larutan. Kegiatan-kegiatan pembelajaran dalam topik sifat koligatif larutan dirancang guru menggunakan model inkuiri dengan strategi conceptual teaching. Model inkuiri yang diterapkan oleh kelompok 2 tersebut menggunakan metode praktikum sesuai dengan kompetensi dasar materi yang akan dicapai. Topik pada kelompok 3 adalah kimia unsur, guru menggunakan model pembelajaran berbasis proyek (project based learning) dalam merancang kegiatan-kegiatan pembelajarannya.

Berdasarkan uraian di atas, didapatkan beberapa temuan sebagai berikut.

1. Kegiatan-kegiatan pembelajaran dalam RPP berbasis model-model pembelajaran inovatif yang disusun guru adalah baik. Hal tersebut mengindikasikan bahwa guru telah mampu menerapkan model-model pembelajaran inovatif dalam pengembangan RPP.

2. Perangkat pendukung RPP seperti Lembar Kegiatan Siswa (LKS) dan lembar asesmen yang disusun guru adalah baik. Hal ini berarti guru telah mampu mengembangkan perangkat pendukung RPP dengan menerapkan model-model pembelajaran inovatif

Angket tentang respon peserta ini diisi peserta setelah kegiatan pelaksanaan pelatihan model-model pembelajaran inovatif. Rekapitulasi respon peserta terhadap pelaksanaan pelatihan model-model pembelajaran inovatif disajikan pada Tabel 3.

Tabel 3 Respon Positif Peserta terhadap Pelatihan Model-Model Pembelajaran Inovatif

\begin{tabular}{|c|c|c|c|}
\hline No & Uraian & Respon & Kategori \\
\hline 1 & Materi pelatihan & $\begin{array}{l}\text { Menarik } \\
100 \%\end{array}$ & Sangat Baik \\
\hline 2 & $\begin{array}{l}\text { Kompetensi narasumber terhadap materi yang menjadi } \\
\text { tanggung jawabnya }\end{array}$ & $\begin{array}{l}\text { Memadai } \\
100 \%\end{array}$ & Sangat Baik \\
\hline 3 & $\begin{array}{l}\text { Penyampaian materi pelatihan oleh narasumber efektif dan } \\
\text { menarik }\end{array}$ & $\begin{array}{c}\mathrm{Ya} \\
94,74 \%\end{array}$ & Sangat Baik \\
\hline 4 & $\begin{array}{l}\text { Model-model pembelajaran inovatif berbasis } \\
\text { penyingkapan/penelitian (discovery/inquiry learning), } \\
\text { pembelajaran berbasis proyek (project based learning), dan } \\
\text { pembelajaran berbasis pemecahan masalah (problem based } \\
\text { learning) dapat diterapkan sesuai karakteristik mapel kimia }\end{array}$ & $\begin{array}{c}\mathrm{Ya} \\
73,68 \%\end{array}$ & Baik \\
\hline 5 & $\begin{array}{l}\text { Terdapat relevansi materi pelatihan dengan tugas mengajar } \\
\text { guru serta bersesuaian dengan kurikulum sekolah }\end{array}$ & $\begin{array}{c}\text { Ya } \\
89,47 \%\end{array}$ & Sangat Baik \\
\hline 6 & $\begin{array}{l}\text { Keefektifan penerapan model-model pembelajaran inovatif } \\
\text { berbasis discovery/inquiry learning, project based learning, } \\
\text { dan problem based learning terhadap keterampilan berpikir } \\
\text { peserta didik }\end{array}$ & $\begin{array}{l}\text { Efektif } \\
89,47 \%\end{array}$ & Sangat Baik \\
\hline 7 & $\begin{array}{l}\text { Model-model pembelajaran inovatif berbasis discovery/inquiry } \\
\text { learning, project based learning, dan problem based learning } \\
\text { membantu peserta didik untuk memahami konsep-konsep } \\
\text { kimia dan melatihkan pemecahan masalah dalam } \\
\text { pembelajaran di kelas. }\end{array}$ & $\begin{array}{l}\text { Membantu } \\
78,95 \%\end{array}$ & Baik \\
\hline 8 & $\begin{array}{l}\text { Model-model pembelajaran inovatif berbasis discovery/inquiry } \\
\text { learning, project based learning, dan problem based learning } \\
\text { berpengaruh terhadap hasil belajar peserta didik }\end{array}$ & $\begin{array}{l}\text { Berpengaruh } \\
84,21 \%\end{array}$ & Baik \\
\hline 9 & $\begin{array}{l}\text { Strategi conceptual change dapat diterapkan pada semua } \\
\text { model-model pembelajaran inovatif }\end{array}$ & $\begin{array}{c}\mathrm{Ya} \\
63,16 \%\end{array}$ & Cukup Baik \\
\hline & $\begin{array}{llll}\text { Berdasarkan data pada Tabel } 3 \text { terlihat } & \text { memperoleh } \\
\text { la hampir semua item respon } & \text { Mayorita }\end{array}$ & $\begin{array}{l}\text { espon baik } \\
\text { eserta me }\end{array}$ & $\begin{array}{l}\text { sangat ba } \\
\text { oon bah }\end{array}$ \\
\hline
\end{tabular}


penyampaian materi oleh tim PKM menarik dan efektif serta model-model pembelajaran inovatif bermanfaat pada tugas mengajar guru dan sesuai dengan kurikulum sekolah.

Untuk item 'Strategi conceptual change dapat diterapkan pada semua model-model pembelajaran inovatif' masih mendapatkan kategori cukup baik. Hal tersebut dikarenakan bahwa guru-guru belum terbiasa menerapkan strategi conceptual change dalam pembelajaran. Namun, para guru yakin bahwa peranan strategi conceptual change dalam penerapan model-model pembelajaran inovatif sangat penting dalam memperbaiki miskonsepsi siswa.

\section{SIMPULAN DAN SARAN}

Berdasarkan tujuan dan hasil pelatihan yang telah diuraikan dapat disimpulkan seperti berikut ini.

1. Pemahaman materi model-model pembelajaran inovatif guru MGMP kimia di Kabupaten Banyuwangi setelah kegiatan pembelajaran dalam rangka penyegaran materi model-model pembelajaran inovatif termasuk kategori baik dan sangat baik.

2. Kemampuan guru MGMP kimia di Kabupaten Banyuwangi dalam menyusun kegiatan-kegiatan pembelajaran berbasis model-model pembelajaran inovatif adalah baik.

3. Secara umum respon guru MGMP kimia di Kabupaten Banyuwangi terhadap kegiatan pelatihan ini adalah baik dan sangat baik.

Kegiatan ini hendaknya dapat ditindak lanjuti, sebagai berikut.

1. Perlu melanjutkan rencana kegiatan PKM tahap berikutnya yaitu mengimplementasikan hasil penyusunan RPP yang menerapkan model-model pembelajaran inovatif.

2. Menyediakan contoh-contoh instrumen pengamatan dalam rangka implementasi hasil penyusunan RPP yang menerapkan model-model pembelajaran inovatif.

\section{DAFTAR PUSTAKA}

Daniel, S. 2007. Profesionalisme Melalui Sertifikasi sebagai Upaya Peningkatan Mutu, Kompetensi, Jumlah dan Kesejahteraan Guru/Dosen. Makalah disampaikan pada Dialog Interaktif 2007 Dirjen Dikdasmen Guru/Dosen se JawaTimur. LPPM Kampus C Unair.

Permennegpan dan RB Nomor 16 tahun 2009 tentang Jabatan Fungsional Guru dan Angka Kreditnya

Peraturan Pemerintah Republik Indonesia Nomor 32 Tahun 2013 tentang Perubahan atas Peraturan Pemerintah Nomor 19 Tahun 2005 tentang Standar Nasional Pendidikan

Peraturan Menteri Pendidikan dan Kebudayaan Republik Indonesia Nomor 59 Tahun 2014 tentang Kurikulum 2013 Sekolah Menengah Atas/Madrasah Aliyah

Peraturan Menteri Pendidikan dan Kebudayaan Republik Indonesia Nomor 103 Tahun 2013 tentang Pembelajaran pada Pendidikan Dasar dan Pendidikan Menengah.

Peraturan Menteri Pendidikan dan Kebudayaan Republik Indonesia Nomor 65 Tahun 2013 tentang Standar Proses

Undang-Undang Nomor 20 Tahun 2003 tentang Sistem Pendidikan Nasional 